\title{
14. COASTAL UPWELLING GRADIENT DURING THE LATE PLEISTOCENE ${ }^{1}$
}

\author{
D. M. Anderson ${ }^{2}$ and W. L. Prell ${ }^{2}$
}

\begin{abstract}
Upwelling occurs during the summer off the coast of Oman when the Asian monsoon produces strong southwest winds in the northern Arabian Sea. Ekman transport driven by the southwest monsoon winds upwells cool nutrient-rich waters along the coast which contrast with the warmer, less productive waters offshore. The spatial pattern of foraminifers in the sediments corresponds with the coastal environmental gradient. The upwelling species Globigerina bulloides dominates the sediment assemblage on the continental margin, while Globigerinita glutinata is more abundant offshore, creating a coastal gradient in fauna. We reconstructed the upwelling faunal gradient using high resolution oxygen isotope stratigraphy to correlate between Hole 723B on the Oman Margin, and a core from the Owen Ridge (RC2761), adjacent Site 722. A gradient similar in magnitude to the present, implying upwelling conditions similar to today existed during each interglacial time during the late Pleistocene interval from 0 to 300 k.y. The gradient was reduced or absent during glacial times implying diminshed southwest winds along the coast of Oman, not strong enough to produce an environmental gradient between the coast and offshore sites.
\end{abstract}

\section{INTRODUCTION}

The southwest monsoon wind produces upwelling along the coast of Oman and a gradient in the surface waters, which are coldest and most nutrient-rich adjacent to the coast. The coastal upwelling gradient is uniquely associated with the monsoon winds, because the northeast trade winds which prevail during the winter do not produce offshore Ekman transport. Increased insolation heats the Asian continent during the summer months creating a pressure gradient between it and the Indian Ocean. The low level winter winds reverse direction and begin to blow from the southwest in April, and reach maximum velocities in July (Luther and O'Brien, 1985). The strongest winds occur in a northeast-southwest trending jet that crosses the Owen Ridge approximately $60^{\circ} \mathrm{E}$ (the Findlater jet) creating a gradient of increasing wind stress between the coast and the Owen Ridge. Upwelling in the northwest Arabian Sea results from a combination of Ekman transport away from a solid boundary (the coast of Oman) and divergence created by the gradient in wind stress associated with the Findlater jet (Swallow, 1984). More than half of the temperature lowering along the coast relative to the central Arabian Sea can be explained as a result of simple Ekman transport, and the modern sea surface temperature (SST) gradient is thus closely linked to the component of the southwest winds parallel to the coast (Prell and Streeter, 1982). The temperatures are lowest along the coast between $18^{\circ}$ and $20^{\circ} \mathrm{N}$, and here we would expect to find the greatest differences in the biota between sites along the continental margin and those farther offshore.

A wide range of observations including plankton tow and sediment samples show that seasonal upwelling in the northwest Arabian Sea produces a unique pattern of planktic foraminifer abundance. Kroon (1988) collected plankton tows which reveal the dominance of Globigerina bulloides in the living assemblage during the monsoon season. Recent sediment trap data have confirmed the dominance of $G$. bulloides in the assemblage produced by summer upwelling, and shown that foraminifer sedimentation during the summer monsoon season is an order of

${ }^{1}$ Prell, W. L., Niitsuma, N., et al., 1991. Proc. ODP, Sci. Results, 117: College Station, TX (Ocean Drilling Program).

2 Dept. of Geological Sciences, Brown University, Providence, RI 02912, U.S.A. magnitude greater than at other times of the year (Curry and Honjo, pers. comm.). Cullen and Prell (1984) produced maps of species abundance in core top samples which show that the dominance of $G$. bulloides in the living assemblage is preserved in the sediments, together with abundant Globigerinita glutinata. Changes in the \% abundance of $G$. bulloides in sediments have been used to infer past variations in upwelling intensity (Prell and Curry, 1981; Prell, 1984). The G. bulloides index contains several potential complications. Like all percentage data, percent $G$. bulloides is influenced by changing abundances of other species. Also, the abundance patterns represent the contribution of several environmental influences in addition to the monsoon, for example, regional changes in temperature, productivity, or salinity not related to the monsoon. To isolate the coastal upwelling component of the faunal response we will calculate the spatial gradient between coastal and offshore sites which is directly associated with monsoon-driven coastal upwelling. The principal advantage of the gradient is that it helps to isolate coastal upwelling from other, regional changes which affect faunal composition on glacial-interglacial timescales because regional influences which affect both sites equally cancel when calculating the gradient.

The primary goal of this study is to analyze planktic foraminifer abundance along the continental margin of Oman, utilizing the new, longer, high resolution record obtained from Site 723. We will compare the margin record with a site located farther offshore where upwelling is less intense to reconstruct the history of the spatial gradient in fauna. Our goal is to produce an alternate view of the effect of the monsoon winds, emphasizing the environmental gradient created by Ekman transport off the coast.

\section{METHODS}

We measured the faunal gradient related to the modern monsoon regime by analyzing 37 core top samples collected during the survey Cruise RC2704 (Fig. 1). On the Oman Margin, 18 samples were obtained from water depths ranging from 400$1400 \mathrm{~m}$. Farther offshore we selected 19 core top samples from the Owen Ridge ranging from 1800 to $4000 \mathrm{~m}$ water depth.

To reconstruct the spatial gradient during the late Pleistocene we selected two sites situated above the lysocline, from approximately the same latitude. Site 723 is located on the continental margin at $800 \mathrm{~m}$ water depth where upwelling is strongest today 


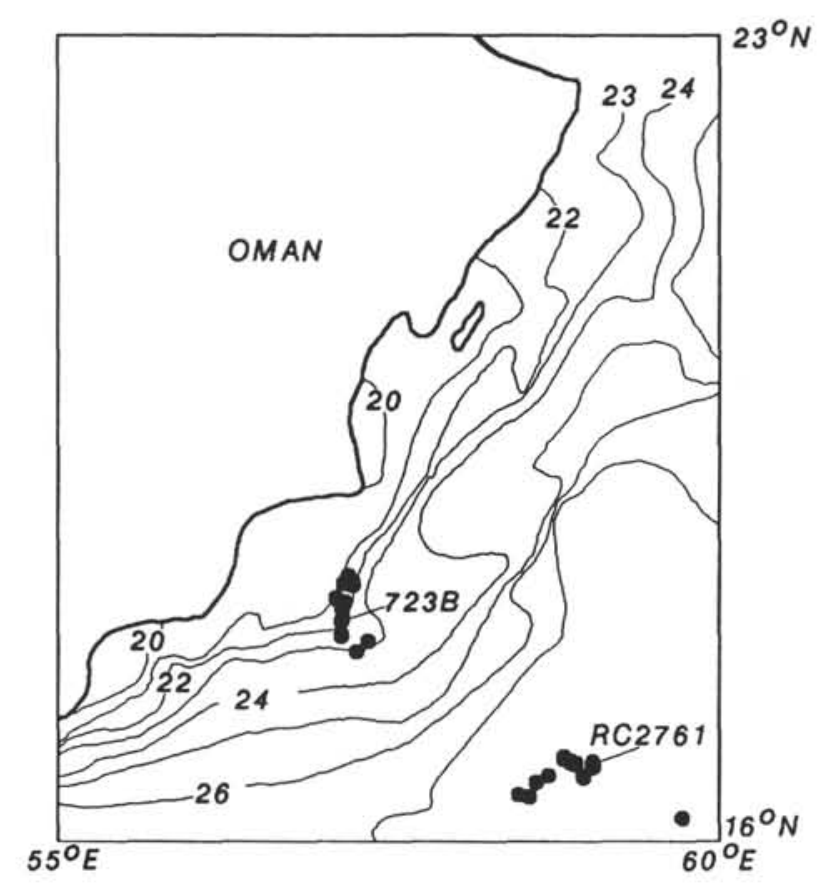

Figure 1. Sea surface temperatures $\left({ }^{\circ} \mathrm{C}\right)$ off Oman during the southwest monsoon (25 June-21 July 1963; from Bruce, 1974) and the location of cores used in this study.

indicated by the coldest SSTs. RC2761 is located $320 \mathrm{~km}$ offshore on the Owen Ridge (1800 m water depth, adjacent Site 722) where upwelling is less intense. To correlate between cores we used high resolution oxygen isotope stratigraphies to provide an age model within the glacial-interglacial framework. Each core was correlated independently to the SPECMAP stacked isotope record (Imbrie et al., 1984). The RC2761 age model is described in Clemens and Prell (in press). The Site $723 \delta^{18} \mathrm{O}$ record is based primarily on Hole $723 \mathrm{~A}$ with patches from Hole 723B (Niitsuma and Oba, this volume). Inverse signal correlation was used to create a non-linear mapping function to the stacked record (Martinson et al., 1982). The procedure was iterated to maximize similarity of the $\delta^{18} \mathrm{O}$ records in the time domain, maximize spectral coherency in each of the orbital bands with minimal phase lags over the coherent intervals, and finally to minimize rapid, large changes in sedimentation rate. The superposition of the three isotope records (Fig. 2) indicates a good match at each glacial-interglacial transition, with most differences less than $5 \mathrm{k}$.y. The correlation is more uncertain during stage 6 when $\delta^{18} \mathrm{O}$ in Hole 723B has little variation.

Counts of the planktic foraminifers were produced using at least 300 individuals split from the $>50 \mu \mathrm{m}$ fraction. We identified 33 species, following the taxonomic conventions of the CLIMAP group (Parker, 1962; Bé, 1977; Saito et al., 1981). CLIMAP recognized an additional species, Neogloboquadrina pachyderma-dutertrei intergrade, based on morphology intermediate between $N$. dutertrei and $N$. pachyderma-right coiling. Our results may differ from studies which do not make this distinction, particularly in older sediments where $N$. pachyderma dutertrei-intergrade increases in abundance. We used the CABFAC version of Q-mode factor analysis (Imbrie and Kipp, 1971) to produce a rotated five-factor solution to the dataset, which consisted of 258 samples from cores RC2761, 117-723B-1H to $117-723 \mathrm{~B}-7 \mathrm{H}$, and 37 core top samples from the site survey cruise. Here we discuss the first three factors which explain more than $93 \%$ of the variance in the dataset.
Reconstructing the gradient involves several problems. The approach is extremely sensitive to errors in the age models. To calculate the spatial gradient we must compare samples which were deposited at the same time. If errors in the age models offset the two time series where they are changing, the calculated difference is erroneous. Second, dissolution may introduce a faunal contrast if the cores are situated at different depths below the lysocline. We will minimize these problems by correlating high resolution ( $5 \mathrm{k} . \mathrm{y}$. interval) oxygen isotope records and by comparing two cores located above the lysocline.

\section{RESULTS}

\section{Species Abundance}

Only 13 species of the 33 species counted average more than $1 \%$ abundance downcore in Hole 723B and Core RC2761. The percent abundance of these species are shown for the margin Site 723 (solid line) and the offshore site RC2761 (dashed line) in Figure 3. Species abundance data for RC2761 are given in Prell (in prep.) and Hole 723B data are listed in Appendix A. In the downcore dataset Globigerina bulloides (average 30\%) and Globigerina glutinata $(13 \%)$ are most abundant throughout, followed by Globigerinoides ruber $(10 \%), N$. dutertrei $(9 \%)$, and Globigerina falconensis $(7 \%)$. N. pachyderma-dutertrei intergrade and $N$. pachyderma-dutertrei right-coiling become more abundant in samples older than $125 \mathrm{k}$.y. The two most abundant species exhibit some variations which are similar at both sites but also large differences in abundance between sites which occur principally during interglacial times.

Among the less abundant species we observe some patterns which are similar to other species patterns and some high frequency variability. To combine those species which vary together, and smooth some of the variability in the dataset which are not part of consistent patterns, we used the CABFAC version of Q-mode factor analysis. In addition to identifying species which covary and separating those which are independent, factor analysis is useful because it tends to smooth the noise in the dataset, and organize the data according to consistent patterns which explain most of the variance within a group of samples. The similarity measure used (cosine theta) reduces slightly the influence of a dominant species in samples dominated by few species, while preserving the relationship between species within a sample. For example, several peaks in $G$. bulloides abundance including the maximum at $50 \mathrm{k} . \mathrm{y}$. are reduced when expressed as factor 1 .

\section{Factor Analysis}

The five factor solution concentrates $93 \%$ of the variance in three factors, summarized in Table 1 . The $\mathrm{F}$ matrix of factor scores is listed in Table 2 . The first factor is a monospecific $G$. bulloides factor (variance $=43 \%$ ). The second factor $(29 \%)$ is dominated by G. glutinata, with a lower score on Globorotalia menardii. The third factor $(24 \%)$ contains almost equal scores for $G$. ruber and $N$. pachyderma-dutertrei intergrade, and lesser amounts of $N$. dutertrei, G. falconensis, G. sacculifer, Globigerina calida, and $N$. pachyderma right coiling. Communality for each of the samples is usually above 0.98 , and is below 0.90 for only three samples (Appendix B). Thus the factor model adequately describes faunal variation within our database of core top and late Pleistocene samples.

\section{Core Top Factor Loadings}

To investigate patterns related to location and water depth we compared the faunal factor loadings of 18 core top samples from the Oman Margin located near Hole 723B with 19 core top samples from the Owen Ridge near RC2761 (Fig. 1). These core top samples contain the last few hundreds of years deposition 


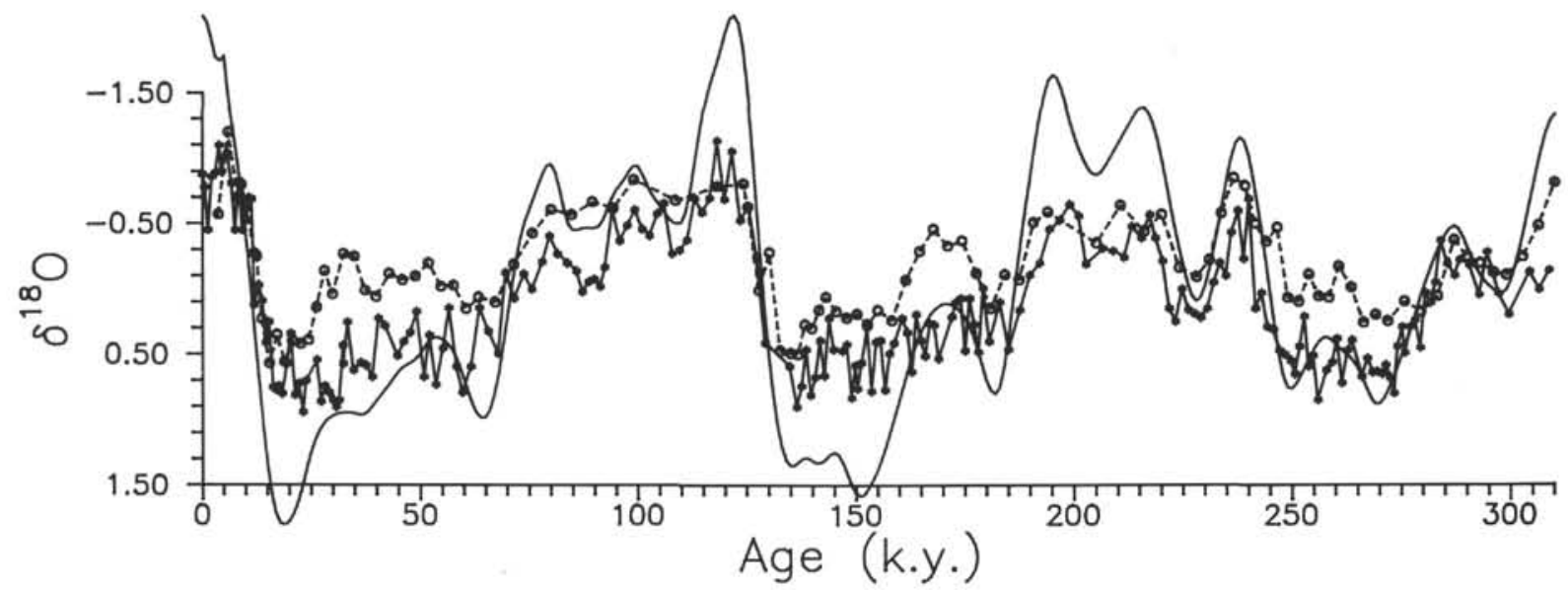

Figure 2. Isotope stratigraphy for Site 723 composite (*), RC2761 (o), and the Imbrie et al. (1984) stacked $\delta^{18} \mathrm{O}$ record. Site 723 and RC2761 values are relative to PDB. The stack is reported in standard deviation units.

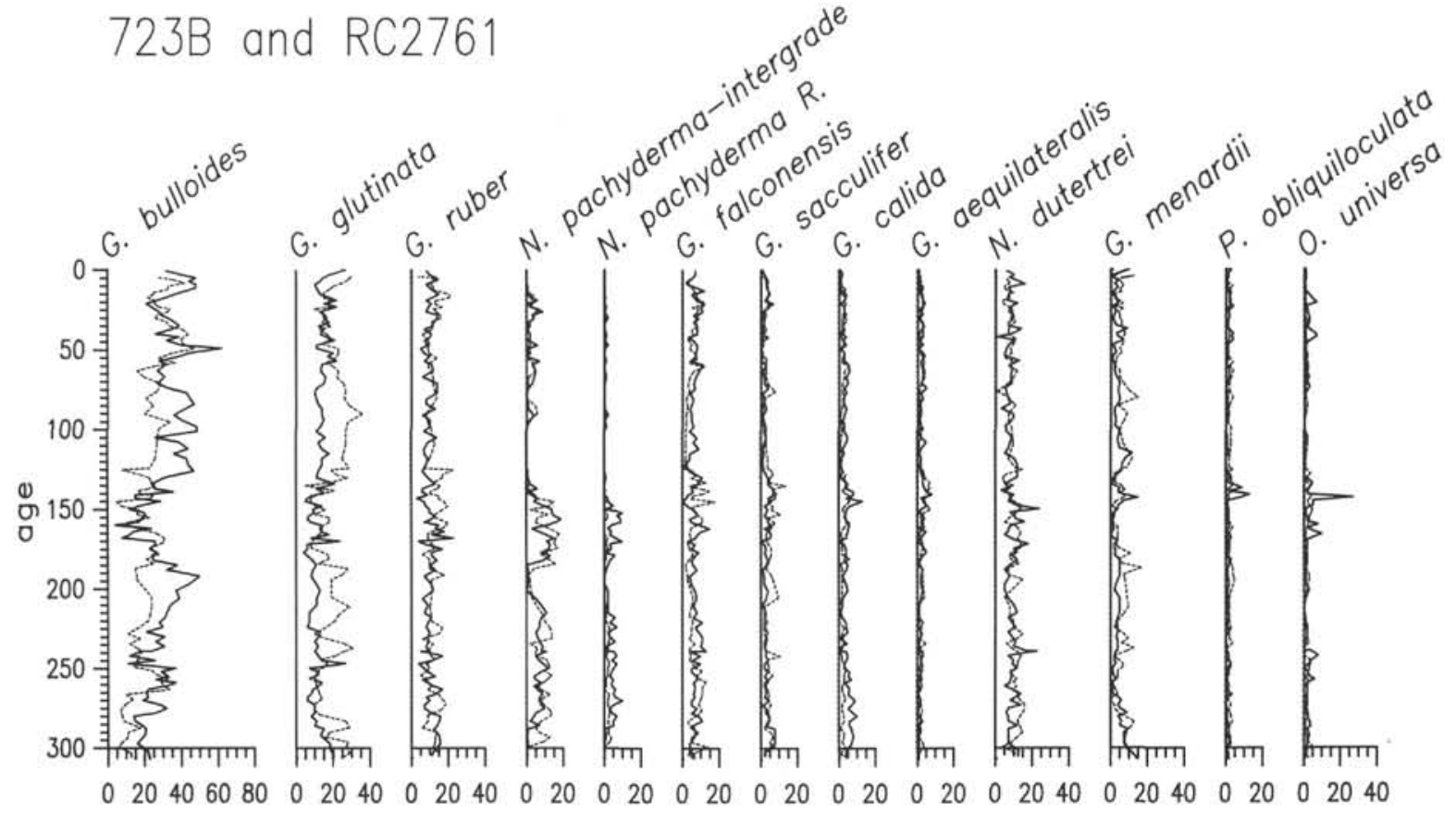

Figure 3. Planktonic foraminifer species abundance (percent) during the late Pleistocene for all species greater than $1 \%$ average abundance in Hole 723B (solid line) and RC2761 (dashed line).

Table 1. Summary statistics for CABFAC factor analysis.

\begin{tabular}{lccc}
\hline & Factor 1 & Factor 2 & Factor 3 \\
\hline Dominant species & $\begin{array}{c}\text { Globigerina } \\
\text { bulloides } \\
\text { Variance explained }\end{array}$ & $\begin{array}{c}\text { Globigerinita } \\
\text { glutinata } \\
\text { 43\% }\end{array}$ & $\begin{array}{l}\text { G. ruber } \\
\text { N. pachyderma inter. }\end{array}$ \\
$\begin{array}{cccc}\text { Oman Margin core tops } \\
\text { Average loading }\end{array}$ & 0.82 & 0.47 & $24 \%$ \\
$\quad$ Standard deviation & 0.08 & 0.13 & 0.23 \\
Owen Ridge core tops & 0.60 & 0.75 & 0.05 \\
$\quad$ Average loading & 0.08 & 0.07 & 0.22 \\
Standard deviation & 0.04 & 0.04 \\
\hline
\end{tabular}

and are thus an estimate of the faunal gradient between coastal and offshore sites associated with the modern and late Holocene monsoon regime. We calculated average loadings at the coast by grouping all Oman Margin samples (which are shallower than $1500 \mathrm{~m}$ ) together, and calculated the average loadings offshore by grouping the Owen Ridge samples, all which lie deeper than $1500 \mathrm{~m}$ water depth (shown as a dashed line on Fig. 4). The core top samples indicate that Factor 1 (F1) and Factor 2 (F2) vary between the margin and the ridge sites, but Factor 3 (F3) is similar at both sites (Fig. 4). F1 loadings average 0.82 on the margin, and decrease by 0.22 to 0.60 at the ridge sites (Table 1). F2 loadings are greatest at the ridge sites ( 0.75$)$, and decrease to 0.47 on the margin. Factor 3 is low in abundance at both sites $(0.23)$. None of the factors show any obvious change with depth 
Table 2. Varimax factor scores from CABFAC factor analysis of 258 samples from core RC2761, Hole 723B, and Cruise RC2704 core top samples.

\begin{tabular}{|c|c|c|c|}
\hline Species & F1 & F2 & F3 \\
\hline Orbulina universa & -0.01 & 0.00 & 0.13 \\
\hline Globigeroides conglobatus & 0.00 & 0.00 & 0.00 \\
\hline Globigeroides ruber & 0.03 & 0.08 & 0.51 \\
\hline Globigeroides tenellus & 0.00 & 0.02 & 0.05 \\
\hline Globigeroides sacculifer & -0.04 & 0.05 & 0.22 \\
\hline Sphaeroidinella dehsicens & 0.00 & 0.00 & 0.00 \\
\hline Globigerinella adamsi & 0.00 & 0.00 & 0.00 \\
\hline Globigerinella aequilateralis & 0.02 & -0.01 & 0.11 \\
\hline Globigerina calida & 0.02 & -0.03 & 0.18 \\
\hline Globigerina bulloides & 0.99 & -0.03 & 0.02 \\
\hline Globigerina falconensis & 0.06 & -0.01 & 0.31 \\
\hline Globigerina digitata & 0.00 & 0.00 & 0.00 \\
\hline Globigerina rubescens & 0.01 & -0.01 & 0.05 \\
\hline Globigerina humilis & 0.00 & 0.00 & 0.00 \\
\hline Globigerina quinquiloba & 0.01 & -0.01 & 0.01 \\
\hline Neogloboquadrina pachyderma left coiling & 0.00 & 0.00 & 0.02 \\
\hline Neogloboquadrina pachyderma right coiling & -0.01 & -0.06 & 0.17 \\
\hline Neogloboquadrina dutertrei & 0.00 & 0.15 & 0.42 \\
\hline Globoquadrina conglomerata & 0.00 & 0.00 & 0.00 \\
\hline Globoquadrina hexagona & -0.01 & 0.02 & 0.00 \\
\hline Pulleniatina obliquiloculata & -0.01 & 0.06 & 0.06 \\
\hline Globorotalia inflata & 0.00 & 0.00 & 0.00 \\
\hline Globorotalia truncatulinoides left coiling & 0.00 & 0.00 & 0.00 \\
\hline Globorotalia truncatulinoides right coiling & 0.00 & 0.00 & 0.01 \\
\hline Globorotalia crassaformis & 0.00 & 0.00 & 0.05 \\
\hline $\begin{array}{c}\text { Globoquadrina pachyderma- } \\
\text { dutertrei intergrade }\end{array}$ & -0.09 & -0.11 & 0.57 \\
\hline Globorotalia hirsuta & 0.00 & 0.00 & 0.00 \\
\hline Globorotalia scitula & 0.01 & -0.01 & 0.01 \\
\hline Globorotalia menardii & 0.01 & 0.31 & -0.03 \\
\hline Globorotalia tumida & 0.01 & 0.04 & -0.02 \\
\hline Globorotalia menardii (flexuosa) & 0.00 & 0.00 & 0.00 \\
\hline Candeina nitida & 0.00 & 0.00 & 0.00 \\
\hline Globigerinita glutinata & 0.02 & 0.92 & -0.02 \\
\hline
\end{tabular}

other than the offset which occurs between the deepest margin site, and the shallowest ridge site.

We estimated the uncertainty in the factor loadings of the core top samples by assuming that the group of 19 ridge core top samples represents the same ridge environment, and that the group of 18 margin core top samples represents the margin environment. Variation within these groups results from counting errors, differences in preservation, or differences in sample age (we assumed all core tops to be Holocene in age on the basis of calcium carbonate stratigraphies). Large differences within a group would suggest that our assumptions are not valid. The standard deviations for the two groups of samples are similar in both environments, approximately 0.08 for $\mathrm{F} 1,0.1$ for $\mathrm{F} 2$, and 0.05 for F3 (Table 1). Compared to these measures of local variability, the magnitude of the core top gradient between the margin and the ridge is approximately three times greater.

\section{Preservation}

Differences in preservation must always be considered when comparing cores, and we analyzed the core top samples for evidence that differences in dissolution might affect the gradient. We made three observations. First, F1 and F2 show no significant change with water depth today over the 500-4000 m range except for the offset which occurs between margin and ridge samples separated by a dashed line on Figure 4 . The foraminifer lysocline is approximately $3300 \mathrm{~m}$ in the Arabian Sea (Cullen and Prell, 1984) but no change in F1 or F2 occurs across this depth. Also, several dissolution susceptible species (Globigerinoides ruber and Globigerina falconensis) are included in F3 which shows no contrast between the margin and the ridge. Finally, we measured the faunal gradient over the interval 0-160 k.y. using two cores from similar water depths $(1400 \mathrm{~m}$ on the margin and $1800 \mathrm{~m}$ on the Owen Ridge) and found a gradient similar to the gradient between Hole 723B and RC2761 samples over the same interval. We concluded that the differences we observed between sites are not a result of differences in preservation.

\section{Factor Loadings During the Late Pleistocene}

The Factor 1 loadings at each site (Fig. 5) are similar to the percent Globigerina bulloides records (Fig. 3). Some patterns are observed at both sites, for example high loadings on the glacial to interglacial transition 9 k.y., during stage 3 , and stage 8 , and decreased loadings during stage 6 .

At other times the F1 record differs between sites. During interglacial stages 1, 5, and 7, F1 loadings are greater on the margin relative to the ridge. Most of the difference results from decreased F1 loadings offshore, where the variability in F1 is greater. We calculated the difference between the ridge loadings and the margin loadings ( $\Delta \mathrm{F} 1, \mathrm{Fig} .5)$ by interpolating each of the records at $3 \mathrm{k} . \mathrm{y}$. intervals (the mean sample interval) and subtracting RC2761 loadings from Site 723 loadings to express the gradient in faunal composition between the margin and the ridge. A positive gradient indicates factor loadings are higher on the margin, and a negative gradient indicates the assemblage is more abundant on the ridge. We calculated a positive gradient in $\mathrm{F} 1$ equal to or greater than the core top difference $(0.22)$ during each interglacial. The difference generally decreases during

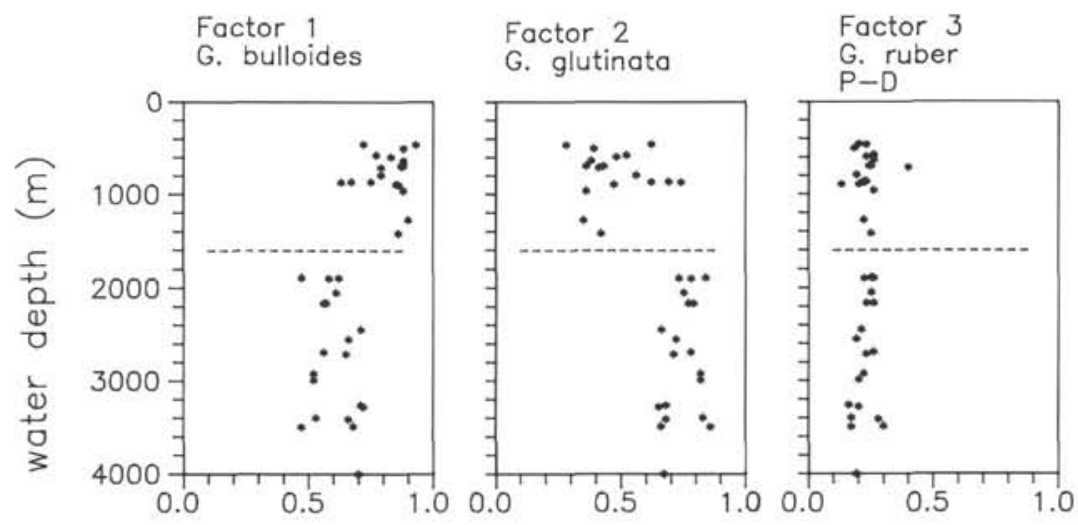

Figure 4. Factor loadings of 37 core top samples collected during cruise RC2704. All samples shallower than $1500 \mathrm{~m}$ water depth are situated near the coast on the Oman Margin, and all deeper samples lie farther offshore on the Owen Ridge. 

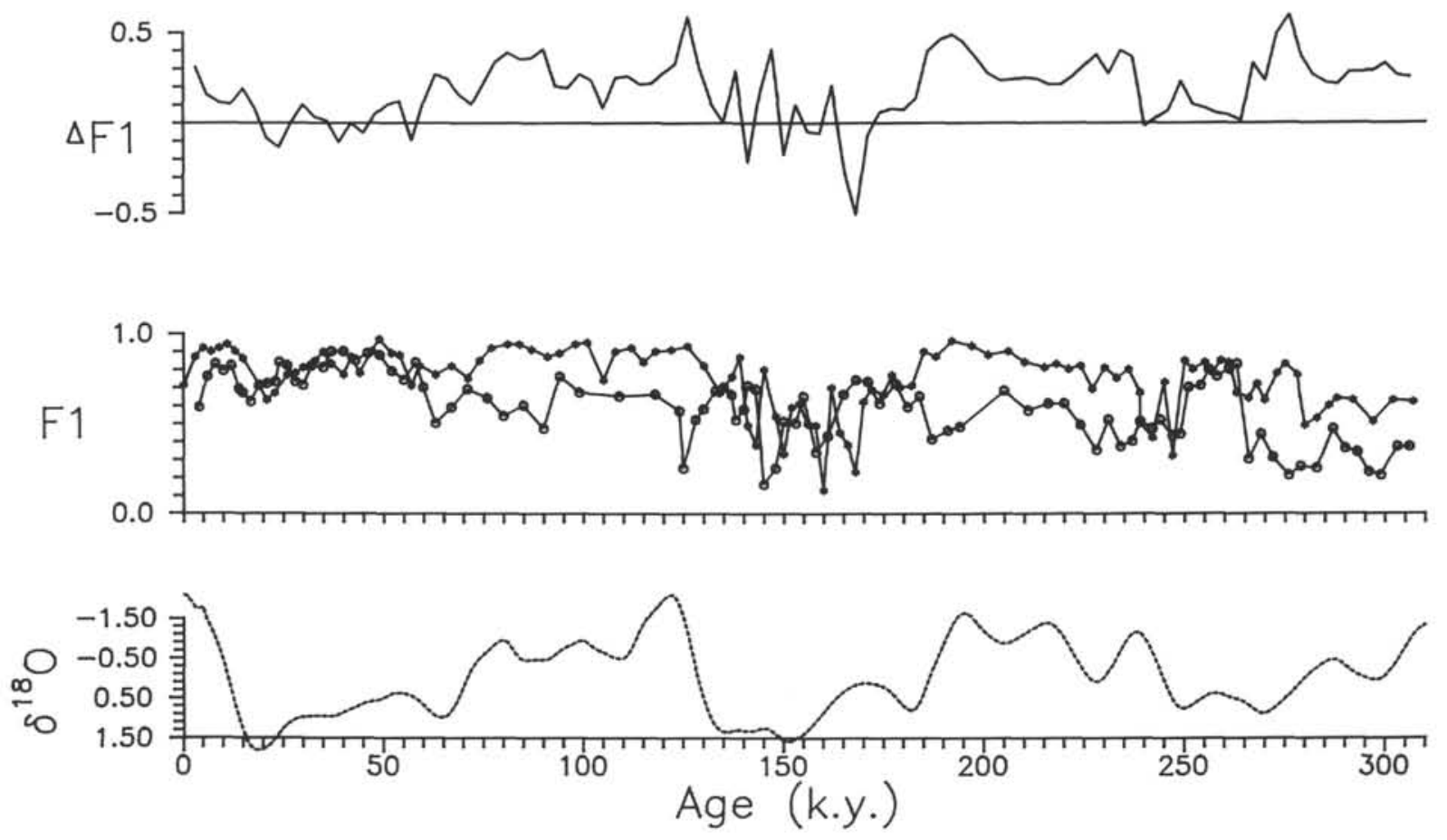

Figure 5. Factor 1 (Globigerina bulloides) loadings in Hole 723B $\left(^{*}\right)$ nearshore and RC2761 (o) offshore during the late Pleistocene. The factor gradient $(\Delta \mathrm{F})$ was calculated by interpolating each record at the mean sample interval $(3 \mathrm{k} . \mathrm{y}$.) and subtracting RC2761 loadings from Hole 723B loadings. The SPECMAP isotopic record is shown for reference.

each glacial stage and is, with some exceptions, close to the level of variability calculated in core top groups of samples $(0.08)$ and attributed to noise.

Factor 2 loadings are low and approximately the same at both sites during glacial stages $2-4$, stage 6 , and stage 8 . During interglacials F2 loadings increase offshore while remaining low on the margin, and we calculated a gradient similar to the core top difference $(0.28)$ during each interglacial time ( $\Delta \mathrm{F} 2$, Fig. 6$)$. During glacials the $\mathrm{F} 2$ gradient decreases. Generally when $\Delta \mathrm{F} 1$ increases $\Delta \mathrm{F} 2$ becomes more negative. Thus during interglacials a gradient in faunal composition is created in two assemblages, and the gradient disappears or is much reduced during glacial times.

In addition to the dominant glacial-interglacial pattern there are peaks in the $\Delta \mathrm{F} 1$ and $\Delta \mathrm{F} 2$ gradient with an approximate periodicity of $20 \mathrm{k}$.y. which occur during interglacial and glacial stages, for example at 35 and $55 \mathrm{k}$.y. during glacial stages 2-4.

A few exceptions to these patterns exist. The gradient is not always zero during glacial times but unlike interglacial times, usually exists in only one factor. During glacial stage 6 the factor loadings are more variable at both sites and the gradient reverses at times ( $\Delta \mathrm{F} 1$ becomes negative), but the pattern is not consistent in both $\Delta \mathrm{F} 1$ and $\Delta \mathrm{F} 2$. In the early part of glacial stage 8 (270-300 k.y.) a gradient in both $\Delta \mathrm{F} 1$ and $\Delta \mathrm{F} 2$ exists during an interval which is not fully glacial with respect to $\delta^{18} \mathrm{O}$ enrichment.

Factor 3 shows no gradient between the margin and the ridge at the core top, and no glacial-interglacial pattern exists during the late Pleistocene interval (Fig. 7). Most of the variations in F3 are similar at both sites except over the interval 270-305 k.y., where they are offset. In general F3 increases during glacials, and becomes more abundant during older glacial intervals. As the factor loadings increase downcore the $\Delta \mathrm{F} 3$ deviations about zero become larger.

\section{DISCUSSION}

The principal result of this analysis is that a gradient in fauna similar in magnitude to the present has existed in each interglacial interval in the late Pleistocene, and that the gradient is reduced during glacial intervals. Although we will concentrate on a factor representation, the gradient is readily apparent in Globigerina bulloides and Globigerinita glutinata percentage data. Our interpretation would not be altered if we looked at the species percentages directly.

\section{Gradient and Abundance Patterns at Each Site}

The gradient time series $(\Delta \mathrm{F} 1)$ is substantially different from the F1 time series at either site. When the gradient exists F1 is actually low in abundance offshore and F1 is abundant at the coast. This observation invalidates a simple paradigm-that when upwelling increases, F1 (Globigerina bulloides) increases at both sites and increases most near the coast. Instead, interglacials are characterized by high F1 loadings nearshore and high F2 loadings offshore, producing a steep faunal contrast between sites. Offshore, F2 is better correlated with the presence of a coastal gradient than F1. The increase in F2 offshore may cause F1 to decrease during interglacials because relative abundances are affected by changes in each species. Interpretations of relative abundance offshore need to consider the competing influence of the two most abundant assemblages.

There are clearly some patterns which are observed in F1 at both sites. F1 shows a long-term increase between $300 \mathrm{k} . \mathrm{y}$. and the present at both sites, and increases in abundance during glacial stages 6 and 8 . We interpret these to be regional changes because they are observed at both sites. Some of these changes may be related to the monsoon, and others may be related to varying input of the tropical species, to ecological changes in Globigerina bulloides, or to other factors not necessarily related 

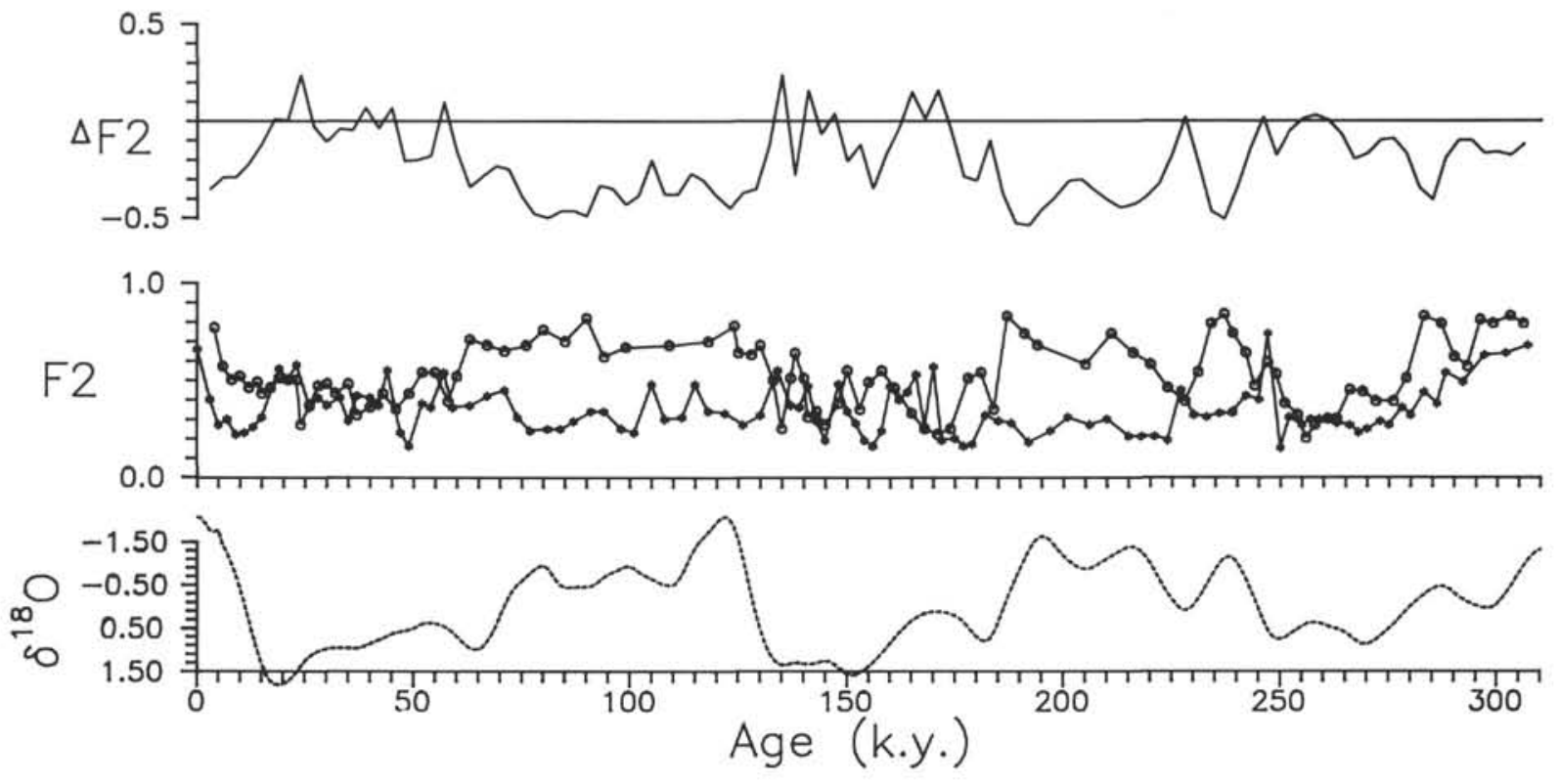

Figure 6. Factor 2 (Globigerinita glutinata) loadings in Hole 723B $\left(^{*}\right)$ nearshore and RC2761 (o) offshore during the late Pleistocene. The factor gradient $(\Delta \mathrm{F})$ was calculated by interpolating each record at the mean sample interval ( 3 k.y.) and subtracting RC2761 loadings from Hole 723B loadings. The SPECMAP isotopic record is shown for reference.
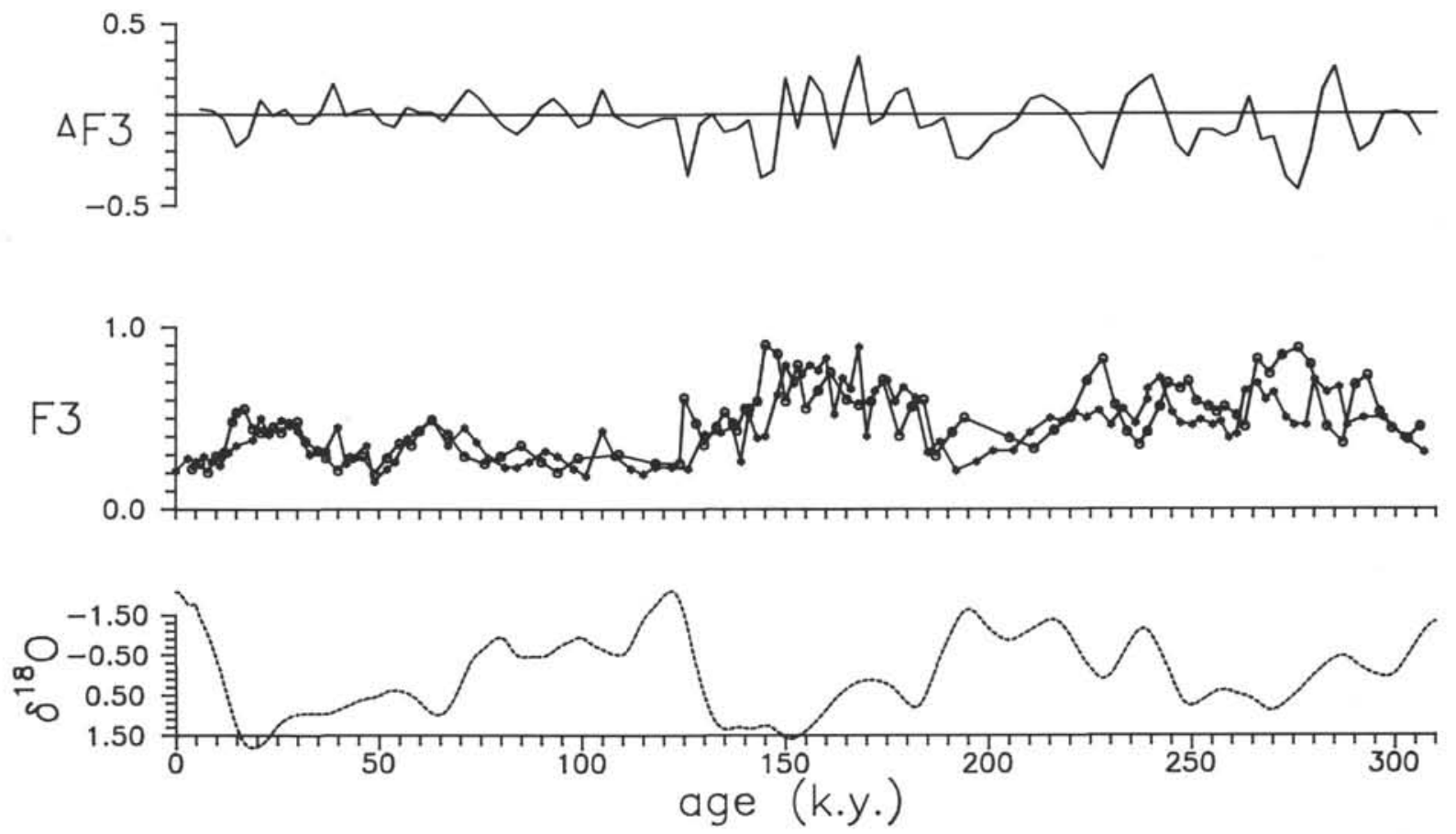

Figure 7. Factor 3 (Globigerinoides ruber, Neogloboquadrina pachyderma-dutertrei intergrade) loadings in Hole 723B $\left({ }^{*}\right)$ nearshore and $\mathrm{RC} 2761$ (o) offshore during the late Pleistocene. The factor gradient $(\Delta \mathrm{F})$ was calculated by interpolating each record at the mean sample interval ( 3 k.y.) and subtracting RC2761 loadings from Hole 723B loadings. The SPECMAP isotopic record is also shown.

directly to the southwest monsoon. Removing these competing influences is the principal advantage of the gradient because changes that affect both sites equally cancel when calculating the difference between sites.

These observations help to explain inconsistencies between the foraminifer fauna and other monsoon indices. Variations in F1 ( $G$. bulloides) at a single site are not well correlated with other monsoon records such as the monsoon pollen record (Prell and Van Campo 1986; Prell and Kutzbach, 1987) or the upwelling history inferred from the barium/aluminum ratio (Shimmield and Mowbray, this volume) but the faunal gradient is similar to these independent monsoon time series. Variations in a single species at a single site have multiple causes which include local processes dependent on the geometry of coastal up- 
welling, regional monsoon-related changes, and some causes which may be independent of the monsoon.

\section{Tropical Assemblage}

The third component of an essentially three component system, F3 is abundant whenever F1 and F2 diminish (Fig. 7). F3 contains many of the tropical species which dominate the eastern Arabian Sea away from the upwelling area although not in exactly the same proportion (Bé and Hutson, 1977; Cullen and Prell, 1984). In the upwelling region, tropical species make up only a small part of the core top assemblage, which is dominated by Globigerina bulloides or Globigerinita glutinata depending on location. F3 may be considered a background, residual assemblage which is diluted by the upwelling species in the northwestern Arabian Sea. Unlike F1 and F2, factor loadings on F3 are similar at both sites, and covary in time. F3 is least abundant during interglacials when a gradient exists, consistent with our interpretation as a residual assemblage diluted by either upwelling factor.

The factor analysis makes an unusual association in F3, combining warm water tropical species with two subpolar species Neogloboquadrina pachyderma dutertrei-intergrade and Neogloboquadrina pachyderma-right-coiling. These two species are rare in the northwestern Arabian Sea today but occur in sediments below the Benguela Current upwelling region off Namibia in the southeast Atlantic, where sea surface temperatures are much colder, approximately $12^{\circ} \mathrm{C}$. The association suggests that for part of the year during glacials surface waters were very cold, either as a result of increased seasonality, or upwelling of colder subsurface waters relative to today. If coastal upwelling were the mechanism, we would expect to see a coastal gradient in Neogloboquadrina pachyderma dutertrei-intergrade, but no gradient is observed. The increase in F3 is regional, and occurs when the gradient is absent. The other explanation, increased seasonality, is consistent with reduced upwelling. Today, August SSTs, cooled by upwelling, are close to January SSTs resulting in low seasonal contrast. If upwelling were reduced, summer SSTs would increase, and remain warmer for a longer interval each summer. Thus the increase in F3 at both sites suggests reduced monsoonal upwelling during glacial times and greater seasonality.

The occurrence of Globigerina falconensis in this assemblage supports our interpretation of increased seasonality at times when we infer reduced upwelling based on the small faunal gradient. Today Globigerina falconensis is most abundant in the northernmost Arabian Sea where the seasonal contrast is greatest (Cullen and Prell 1984), and low in abundance in Oman Margin and Owen Ridge core top samples. During glacial times when the gradient is absent the presence of Globigerina falconensis increases. We suggest that the region of high seasonality extended farther south to the Oman Margin and Owen Ridge at these times.

\section{Diminished Southwest Winds at the Coast}

We attribute the faunal differences between these two closely spaced sites primarily to the SST difference resulting from Ekman transport driven by southwest monsoon winds at the coast. The SST contrast is a necessary geostrophic adjustment to wind stress on the surface layer at the coast, and the magnitude of the SST difference is directly related to the component of the southwest wind which is parallel to the coast. Geostrophic balance is achieved when the density difference in the surface layer produces a pressure force which balances the coriolis force associated with a northward flowing current. The scale of the geostrophic response is on the order of $50 \mathrm{~km}$. Wind stress at the coast produces a density gradient between the margin and the offshore sites to maintain geostrophic balance. We conclude from the reduced faunal gradient that the wind speed at the coast was not strong enough to produce a significant environmental contrast during glacial times.

The jet structure of the surface windfield may contribute to the gradient, although today more than $66 \%$ of the SST gradient can be explained by coastal Ekman transport (Prell and Streeter, 1982). The southwest winds are strongest offshore approximately $60^{\circ} \mathrm{E}$ focused in the Findlater jet. This structure creates a region of positive wind stress curl extending offshore from the coast to the axis of the jet. Within this region the positive curl causes divergence of the surface waters and mid-ocean upwelling (Swallow, 1984), contributing to the upwelling and SST cooling which occurs off Oman, and extending the region of upwelling offshore to the axis of the jet. Today the greatest positive wind stress curl occurs near the coast and is lower near the offshore site (Swallow, 1984), enhancing the contrast between sites. If the gradient in wind stress related to the Findlater jet diminished or were displaced during glacial times the environmental contrast would be affected. The data are consistent with a narrower jet during glacials which would decrease wind speed at the coast and move the maximum wind stress curl offshore. The small reversal in the gradient (increased F1) offshore observed at some times during glacials supports the hypothesis that the gradient in wind stress increased offshore.

We cannot distinguish from our data between a uniform decrease in low level winds and a narrower jet. Both changes are likely to result from a reduced land-sea monsoon pressure gradient, and both changes would decrease the wind speed at the coast. In addition to these explanations, at least two alternate explanations can be proposed, both of which involve a change in the geometry in the windfield and cannot be fully resolved without more cores. The direction of the southwest winds may have changed, reducing the vector component of the southwest wind parallel to the coast. Alternately, the axis of the jet may have moved farther offshore, without decreasing in velocity. More cores located in the central Arabian Sea are necessary to constrain the movement of the Findlater jet.

\section{Comparison with Pollen Evidence}

Comparison of the upwelling gradient signal to a monsoon pollen index, reflecting pollen derived from east Africa and southwest Arabia (Prell and Van Campo, 1986) is also consistent with diminished southwest winds during glacials. These taxa are transported into the region from the west and southwest primarily by the southwest winds (Van Campo et al., 1982). Decreases in pollen abundance are related either to a decrease in the intensity of the southwest winds or a decrease in pollen at the source area, both of which indicate a weaker monsoon. These pollen are least abundant during stages 2-4 (when no upwelling gradient exists) and are more abundant during interglacial stages 1 and 5 . The decrease in pollen during stages $2-4$ has been interpreted to indicate diminished southwest winds, in agreement with the lack of a gradient in the plankton fauna (Van Campo et al., 1982; Prell and Van Campo, 1986). The pollen record is more similar to the upwelling gradient index than to variations of $\mathrm{F} 1$ in either core, in agreement with our observation that several factors may in combination influence F1 whereas pollen transport and the gradient derived from foraminifer abundance are more directly linked to the southwest winds.

\section{Comparison with General Circulation Model Experiments}

We compared the spatial gradient with general circulation model (GCM) simulations of atmospheric circulation at three times, 0 k.y., 9 k.y., and 18 k.y. GCMs use as input variables, insolation, and physical boundary conditions (including SST, 
glacial ice volume, and land albedo) to make steady state climate simulations (Kutzbach and Guetter, 1986). For the perpetual July simulation today ( 0 k.y.), the GCM realistically simulates the strong southwest winds in the Arabian Sea. At 9 k.y., northern hemisphere summer insolation used as model input is $8 \%$ greater relative to today, and the model simulates stronger southwest winds. For 18 k.y., insolation input was similar to today but glacial boundary conditions were used by the model. The modelled southwest winds were greatly reduced in the Arabian Sea during glacial times.

The GCM results are consistent with the gradient pattern. During the last glacial when the gradient is absent the GCM predicts diminished southwest winds. At 0 k.y. and 9 k.y. GCM predicts strong winds, and we observe a maximal gradient. The GCM predicts slightly stronger winds at 9 k.y. relative to the present whereas no difference is observed in the gradient, but the comparison is equivocal. The small increase implied by the GCM simulated winds may be close to the noise level shown in core top variability. Analysis subsequent to this project revealed that the SST difference calculated from these faunal data was increased at 9 k.y. relative to the core top average, in better agreement with the GCM simulation. The faunal gradient is a direct approach but the SST transfer function may be more successful in integrating all the information implied by the changes in fauna.

The geologic data support the conclusion based on GCM simulations by Kutzbach and Guetter (1986) and others that glacial boundary conditions including increased albedo over Asia and increased SSTs in the western Indian Ocean have a large effect on the land-sea pressure difference, weakening the southwest monsoon winds during glacial times. While insolation changes are important, the faunal gradient indicates that glacial boundary conditions have a larger effect on the monsoon winds than changes in insolation.

\section{CONCLUSIONS}

We present the first high resolution (5 k.y. interval) record of foraminifer abundance from the Oman continental margin where Arabian Sea upwelling is strongest today, and use two cores to reconstruct the spatial gradient in foraminifer abundance which is associated with the environmental gradient produced by coastal upwelling.

The spatial gradient in fauna provides an alternate view of monsoon intensity which emphasizes the environmental gradient created by Ekman transport in response to the southwest monsoon winds. Because regional variables which affect both sites equally cancel when calculating the difference between sites, the gradient isolates the coastal upwelling effect from other regional controls on the fauna. A gradient similar in magnitude to the present has existed during each interglacial stage during the interval 0-300 k.y. While the abundance of Globigerina bulloides has increased during the late Pleistocene, the gradient in fauna has remained approximately constant. The presence of the gradient coincides with increases in the abundance of pollen thought to be transported into the region by southwest winds. During glacials the gradient is absent, implying diminished southeast winds at the coast not strong enough to produce a coastal gradient in temperature and nutrients. During some glacial times the foraminifer $G$. bulloides remains abundant at both margin and ridge sites suggesting that another, regional mechanism maintains or enhances upwelling in the absence of a significant coastal gradient.

\section{ACKNOWLEDGMENTS}

We thank April Martin for help with the foraminifer census, and Alan Mix and two anonymous reviewers for useful comments on the manuscript. This research was supported by a US-
SAC grant to David Anderson. This study would not have been possible without the National Science Foundation support of the Lamont-Doherty Geological Observatory Core Laboratory (Core RC2761); and the support of the Ocean Drilling Program and its core curation by NSF and other organizations.

\section{REFERENCES}

Bé, A.W.H., 1977. An ecological, zoogeographic, and taxonomic review of Recent planktonic foraminifera. In Ramsay, A. T. (Ed.), Oceanic Micropaleontology: London (Academic Press), 1-88.

Bé, A.W.H., and Hutson, W. H., 1977. Ecology of planktonic foraminifera and biogeographic patterns of life and fossil assemblages in the Indian Ocean. Micropaleontology, 23:369-414.

Bruce, J. G., 1974. Some details of upwelling off the Somali and Arabian coasts. J. Mar. Res., 32:419-422.

Clemens, S. C., and Prell, W. L., in press. Late Pleistocene variability of Arabian Sea summer-monsoon winds and dust source-area aridity: an eolian record from the lithogenic component of deep-sea sediments. Paleoceanography.

Cullen, J. L. and Prell, W. L., 1984. Planktonic foraminifera of the northern Indian Ocean: distribution and preservation in surface sediments. Mar. Micropaleontol., 9:1-52.

Imbrie, J., Hays, J. D., Martinson, D. G., McIntyre, A., Mix, A. C., Morley, J. J., Pisias, N. G., Prell, W. L., and Shackleton, N. J., 1984. The orbital theory of Pleistocene climate: support from a revised chronology of the marine delta $\delta^{18} \mathrm{O}$ record. In Berger, A., Imbrie, J., Hays, J., Kukla, G., and Saltzman, B. (Eds.), Milankovitch and Climate (Pt. 1): Dordrecht (D. Reidel), 269-305.

Imbrie, J., and Kipp, N. G., 1971. A new micropaleontological method for paleoclimatology: application to a late Pleistocene Caribbean core. In Turekian, K. K. (Ed.), The Late Cenozoic Glacial Ages: New Haven (Yale Univ. Press), 71-181.

Kroon, D., 1988. Distribution of extant planktic foraminiferal assemblages in Red Sea and northern Indian Ocean surface waters. In Brummer, G.J.A., and Kroon, D. (Eds.), Planktonic Foraminifers as Tracers of Ocean-Climate History: Amsterdam (Free Univ. Press), 229-270.

Kutzbach, J. E., and Guetter, P. J., 1986. The influence of changing orbital parameters and surface boundary conditions on climate simulations for the past 18,000 years. J. Atmos. Sci., 43:1726-1759.

Luther, M. E., and O'Brien, J. J., 1985. A model of the seasonal circulation in the Arabian Sea forced by observed winds. Prog. Oceanog., $14: 353-385$.

Martinson, D. G., Menke, W., and Stoffa, P., 1982. An inverse approach to signal correlation. J. Geophys. Res., 88:4807-4818.

Parker, F. L., 1962. Planktonic foraminiferal species in Pacific sediments. Micropaleontology, 8:219-254.

Prell, W. L., 1984. Variation of monsoonal upwelling: a response to changing solar radiation. In Hansen, J. E., and Takahashi, T. (Eds.), Climatic Processes and Climate Sensitivity. Am. Geophys. Union, Maurice Ewing Series, 29:48-57.

Prell, W. L., and Curry, W. B., 1981. Faunal and isotopic indices of monsoonal upwelling: western Arabian Sea. Oceanol. Acta, 4:9198.

Prell, W. L., and Kutzbach, J. E., 1987. Monsoon variability over the past 150,000 years. J. Geophys. Res., 92:8411-8425.

Prell, W. L., and Streeter, H. F., 1982. Temporal and spatial patterns of monsoonal upwelling along Arabia: a modern analogue for the interpretation of Quaternary SST anomalies. J. Mar. Res., 40:143155.

Prell, W. L., and Van Campo, E., 1986. Coherent response of Arabian Sea upwelling and pollen transport to late Quaternary monsoonal winds. Nature, 323:526-528.

Saito, T., Thompson, P. R., and Breger, D., 1981. Systematic Index of Recent and Pleistocene Planktonic Foraminifera: Tokyo (Univ. of Tokyo).

Swallow, J. C., 1984. Some aspects of the physical oceanography of the Indian Ocean. Deep Sea Res. Part A, 31:639-650.

Van Campo, E., Duplessey, J. C., and Rossignol-Strick, M., 1982. Climatic conditions deduced from a $150-k$.y. oxygen isotope-pollen record from the Arabian Sea. Nature, 296:56-59.

Date of initial receipt: 25 September 1989

Date of acceptance: 8 May 1990

Ms 117B-144 
APPENDIX

Hole 723B Planktic Foraminifer Abundance (Percent)

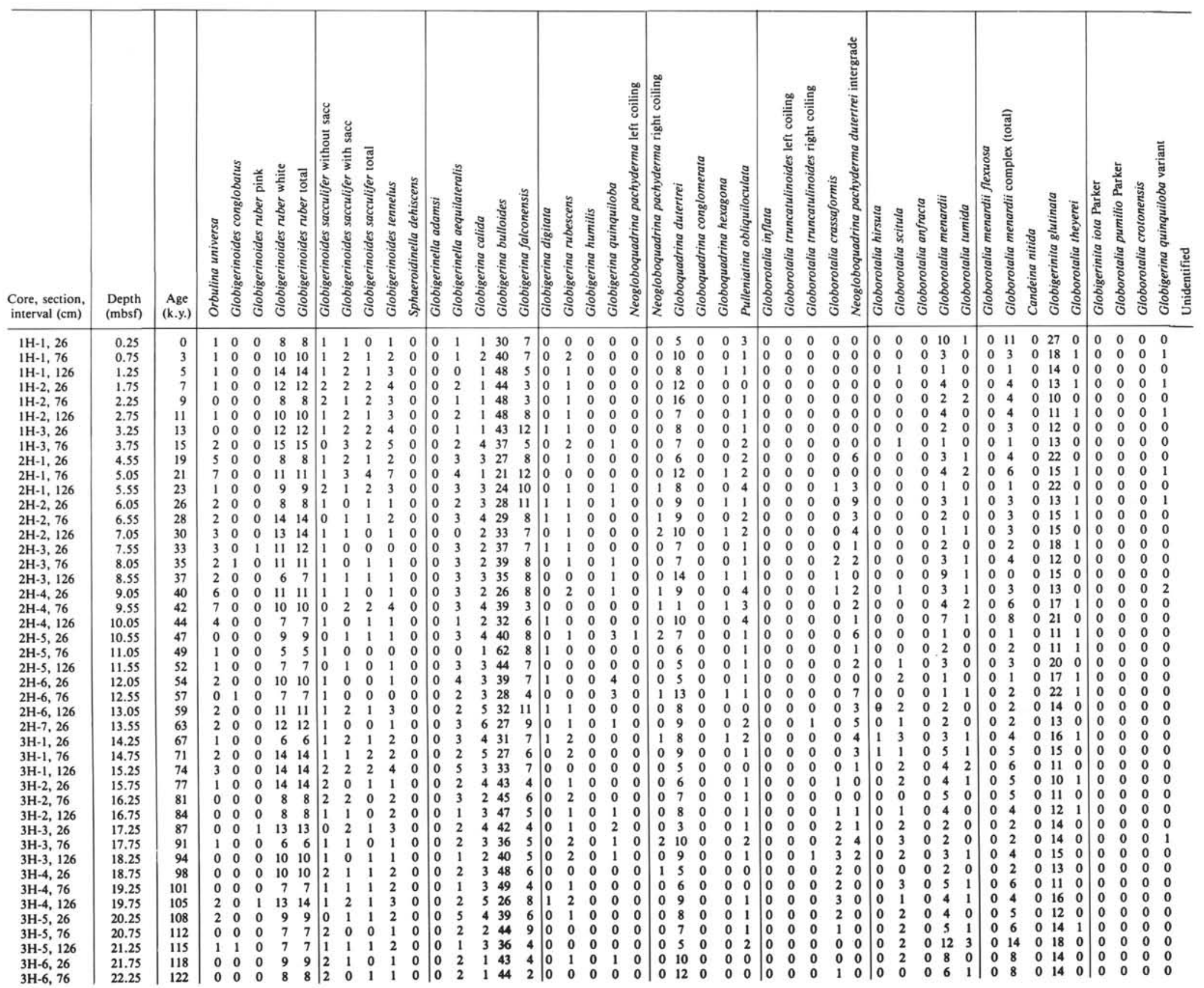


APPENDIX B

CABFAC Communality and Factor Loadings for Hole 723B and Core RC2761

\begin{tabular}{|c|c|c|c|c|c|c|c|c|c|c|c|c|c|c|c|}
\hline \multicolumn{3}{|c|}{ Core RC2761 } & \multirow[b]{2}{*}{ F1 } & \multirow[b]{2}{*}{ F2 } & & & & & Hole & 23B & & & & & \\
\hline $\begin{array}{l}\text { Depth } \\
\text { (m) }\end{array}$ & $\begin{array}{c}\text { Age } \\
\text { (k.y.) }\end{array}$ & Communality & & & F3 & F4 & F5 & $\begin{array}{l}\text { Depth } \\
\text { (mbsf) }\end{array}$ & $\begin{array}{c}\text { Age } \\
\text { (k.y.) }\end{array}$ & Communality & F1 & F2 & F3 & F4 & F5 \\
\hline 0.02 & 4 & 0.99 & 0.59 & 0.77 & 0.22 & -0.02 & 0.02 & 0.25 & 0 & 0.99 & 0.71 & 0.66 & 0.21 & 0.03 & -0.06 \\
\hline 0.12 & 6 & 0.98 & 0.76 & 0.57 & 0.25 & 0.09 & -0.02 & 0.75 & 3 & 0.99 & 0.87 & 0.40 & 0.28 & 0.02 & -0.02 \\
\hline 0.22 & 8 & 0.99 & 0.83 & 0.50 & 0.20 & -0.01 & 0.01 & 1.25 & 5 & 0.99 & 0.92 & 0.27 & 0.26 & 0.07 & 0.02 \\
\hline 0.32 & 10 & 0.99 & 0.79 & 0.52 & 0.29 & 0.09 & 0.02 & 1.75 & 7 & 0.99 & 0.90 & 0.30 & 0.29 & 0.01 & 0.09 \\
\hline 0.42 & 12 & 1.00 & 0.82 & 0.46 & 0.31 & 0.12 & -0.02 & 2.25 & 9 & 0.97 & 0.92 & 0.22 & 0.26 & -0.08 & 0.09 \\
\hline 0.52 & 14 & 0.98 & 0.69 & 0.49 & 0.48 & 0.18 & 0.11 & 2.75 & 11 & 1.00 & 0.94 & 0.23 & 0.24 & 0.04 & 0.00 \\
\hline 0.62 & 15 & 0.98 & 0.67 & 0.43 & 0.53 & 0.24 & 0.01 & 3.25 & 13 & 0.99 & 0.90 & 0.26 & 0.31 & 0.09 & -0.05 \\
\hline 0.72 & 17 & 0.98 & 0.62 & 0.46 & 0.55 & 0.28 & 0.03 & 3.75 & 15 & 0.99 & 0.86 & 0.31 & 0.35 & 0.15 & 0.03 \\
\hline 0.82 & 19 & 0.99 & 0.71 & 0.51 & 0.44 & 0.15 & -0.13 & 4.55 & 19 & 0.98 & 0.71 & 0.56 & 0.38 & 0.00 & -0.15 \\
\hline 0.92 & 21 & 0.98 & 0.72 & 0.50 & 0.42 & 0.16 & -0.08 & 5.05 & 21 & 0.92 & 0.63 & 0.50 & 0.50 & 0.14 & -0.01 \\
\hline 1.02 & 23 & 0.99 & 0.73 & 0.50 & 0.42 & 0.17 & -0.01 & 5.55 & 23 & 0.99 & 0.67 & 0.58 & 0.41 & 0.06 & -0.17 \\
\hline 1.12 & 24 & 0.98 & 0.84 & 0.27 & 0.45 & -0.01 & 0.01 & 6.05 & 26 & 0.98 & 0.77 & 0.36 & 0.49 & -0.07 & -0.13 \\
\hline 1.22 & 26 & 0.99 & 0.82 & 0.37 & 0.42 & 0.08 & -0.01 & 6.55 & 28 & 0.99 & 0.78 & 0.41 & 0.46 & 0.10 & -0.02 \\
\hline 1.32 & 28 & 0.99 & 0.73 & 0.47 & 0.47 & 0.09 & 0.06 & 7.05 & 30 & 0.98 & 0.81 & 0.37 & 0.43 & 0.04 & -0.02 \\
\hline 1.42 & 30 & 0.99 & 0.71 & 0.48 & 0.48 & 0.13 & -0.01 & 7.55 & 33 & 0.99 & 0.85 & 0.41 & 0.30 & 0.07 & -0.05 \\
\hline 1.52 & 32 & 0.99 & 0.82 & 0.43 & 0.37 & 0.03 & 0.08 & 8.05 & 35 & 0.99 & 0.90 & 0.29 & 0.32 & 0.05 & -0.02 \\
\hline 1.62 & 35 & 1.00 & 0.81 & 0.48 & 0.32 & 0.08 & -0.01 & 8.55 & 37 & 0.97 & 0.83 & 0.42 & 0.32 & -0.06 & 0.08 \\
\hline 1.72 & 37 & 1.00 & 0.90 & 0.32 & 0.28 & 0.04 & 0.07 & 9.05 & 40 & 0.96 & 0.77 & 0.41 & 0.45 & 0.08 & 0.00 \\
\hline 1.82 & 40 & 1.00 & 0.90 & 0.36 & 0.21 & -0.05 & -0.01 & 9.55 & 42 & 0.96 & 0.87 & 0.37 & 0.25 & 0.08 & -0.02 \\
\hline 1.92 & 43 & 1.00 & 0.85 & 0.43 & 0.28 & -0.05 & 0.05 & 10.1 & 44 & 0.99 & 0.78 & 0.55 & 0.28 & -0.04 & 0.00 \\
\hline 2.02 & 46 & 1.00 & 0.89 & 0.35 & 0.29 & -0.03 & 0.07 & 10.6 & 47 & 0.99 & 0.90 & 0.23 & 0.35 & -0.02 & -0.08 \\
\hline 2.12 & 49 & 1.00 & 0.88 & 0.43 & 0.19 & -0.03 & -0.03 & 11.1 & 49 & 1.00 & 0.97 & 0.16 & 0.15 & -0.04 & -0.05 \\
\hline 2.22 & 52 & 0.99 & 0.79 & 0.54 & 0.28 & 0.01 & -0.04 & 11.6 & 52 & 1.00 & 0.89 & 0.38 & 0.22 & -0.00 & -0.10 \\
\hline 2.32 & 55 & 0.99 & 0.74 & 0.54 & 0.36 & 0.16 & -0.07 & 12.1 & 54 & 0.98 & 0.88 & 0.36 & 0.26 & 0.08 & -0.07 \\
\hline 2.42 & 58 & 0.99 & 0.84 & 0.39 & 0.35 & -0.03 & 0.02 & 12.6 & 57 & 0.97 & 0.71 & 0.54 & 0.39 & -0.14 & -0.08 \\
\hline 2.52 & 60 & 0.99 & 0.70 & 0.52 & 0.43 & 0.08 & -0.19 & 13.1 & 59 & 0.99 & 0.82 & 0.36 & 0.42 & 0.09 & -0.09 \\
\hline 2.62 & 63 & 0.98 & 0.50 & 0.71 & 0.49 & 0.01 & -0.01 & 13.6 & 63 & 0.98 & 0.77 & 0.37 & 0.50 & 0.07 & -0.05 \\
\hline 2.72 & 67 & 0.98 & 0.59 & 0.68 & 0.41 & 0.09 & 0.04 & 14.3 & 67 & 0.99 & 0.82 & 0.42 & 0.35 & -0.04 & -0.08 \\
\hline 2.82 & 71 & 0.99 & 0.69 & 0.65 & 0.29 & 0.05 & 0.01 & 14.8 & 71 & 0.99 & 0.75 & 0.45 & 0.45 & 0.09 & 0.05 \\
\hline 2.92 & 76 & 0.96 & 0.64 & 0.68 & 0.25 & 0.16 & -0.00 & 15.3 & 74 & 0.99 & 0.85 & 0.31 & 0.37 & 0.17 & 0.03 \\
\hline 3.02 & 80 & 0.98 & 0.54 & 0.76 & 0.29 & 0.06 & 0.16 & 15.8 & 77 & 0.99 & 0.92 & 0.24 & 0.28 & 0.09 & 0.08 \\
\hline 3.12 & 85 & 0.98 & 0.60 & 0.70 & 0.35 & -0.04 & -0.05 & 16.3 & 81 & 1.00 & 0.94 & 0.25 & 0.23 & 0.01 & 0.02 \\
\hline 3.22 & 90 & 0.98 & 0.47 & 0.82 & 0.26 & -0.08 & -0.09 & 16.8 & 84 & 1.00 & 0.94 & 0.25 & 0.23 & -0.02 & 0.02 \\
\hline 3.32 & 94 & 0.99 & 0.76 & 0.62 & 0.20 & -0.00 & -0.01 & 17.3 & 87 & 0.98 & 0.91 & 0.29 & 0.26 & 0.11 & -0.00 \\
\hline 3.42 & 99 & 0.98 & 0.67 & 0.67 & 0.28 & 0.04 & 0.01 & 17.8 & 91 & 0.99 & 0.87 & 0.34 & 0.32 & -0.09 & -0.03 \\
\hline 3.52 & 109 & 0.99 & 0.65 & 0.68 & 0.30 & 0.05 & 0.05 & 18.3 & 94 & 0.99 & 0.89 & 0.34 & 0.29 & -0.01 & 0.01 \\
\hline 3.62 & 118 & 0.99 & 0.66 & 0.70 & 0.25 & 0.03 & 0.08 & 18.8 & 98 & 1.00 & 0.94 & 0.25 & 0.22 & 0.05 & -0.02 \\
\hline 3.72 & 124 & 0.99 & 0.57 & 0.78 & 0.25 & -0.06 & 0.05 & 19.3 & 101 & 1.00 & 0.95 & 0.23 & 0.18 & -0.01 & 0.03 \\
\hline 3.76 & 125 & 0.96 & 0.25 & 0.64 & 0.61 & 0.26 & 0.22 & 19.8 & 105 & 0.99 & 0.74 & 0.48 & 0.43 & 0.16 & 0.03 \\
\hline 3.86 & 128 & 0.98 & 0.52 & 0.63 & 0.47 & 0.28 & -0.06 & 20.3 & 108 & 0.99 & 0.90 & 0.30 & 0.29 & 0.04 & 0.03 \\
\hline 3.96 & 130 & 0.98 & 0.58 & 0.68 & 0.35 & 0.22 & -0.06 & 20.8 & 112 & 0.99 & 0.92 & 0.31 & 0.22 & 0.00 & -0.04 \\
\hline 4.06 & 133 & 0.98 & 0.68 & 0.50 & 0.45 & 0.21 & -0.17 & 21.3 & 115 & 0.98 & 0.84 & 0.48 & 0.19 & -0.01 & 0.07 \\
\hline 4.16 & 135 & 0.93 & 0.70 & 0.25 & 0.53 & 0.21 & 0.25 & 21.8 & 118 & 0.99 & 0.90 & 0.34 & 0.23 & -0.03 & 0.09 \\
\hline 4.26 & 137 & 0.97 & 0.66 & 0.51 & 0.47 & 0.24 & -0.03 & 22.3 & 122 & 0.99 & 0.91 & 0.33 & 0.23 & -0.07 & 0.09 \\
\hline 4.36 & 138 & 0.95 & 0.52 & 0.64 & 0.43 & 0.23 & -0.17 & 22.8 & 126 & 0.99 & 0.93 & 0.27 & 0.22 & -0.07 & 0.07 \\
\hline 4.46 & 140 & 0.93 & 0.58 & 0.51 & 0.55 & 0.17 & -0.08 & 23.3 & 130 & 0.95 & 0.82 & 0.32 & 0.41 & 0.04 & -0.02 \\
\hline 4.56 & 141 & 0.96 & 0.71 & 0.31 & 0.55 & 0.15 & 0.17 & 23.9 & 134 & 0.97 & 0.67 & 0.55 & 0.42 & 0.19 & -0.13 \\
\hline 4.66 & 143 & 0.98 & 0.69 & 0.34 & 0.59 & 0.15 & 0.15 & 24.4 & 137 & 0.91 & 0.76 & 0.37 & 0.45 & -0.04 & 0.03 \\
\hline 4.76 & 145 & 0.94 & 0.16 & 0.27 & 0.90 & 0.13 & -0.15 & 24.9 & 139 & 0.96 & 0.87 & 0.36 & 0.26 & 0.08 & -0.04 \\
\hline 4.86 & 148 & 0.94 & 0.25 & 0.38 & 0.85 & 0.10 & 0.10 & 25.4 & 141 & 0.79 & 0.49 & 0.47 & 0.52 & 0.07 & 0.21 \\
\hline 4.96 & 150 & 0.96 & 0.51 & 0.55 & 0.59 & 0.18 & 0.12 & 25.9 & 143 & 0.45 & 0.38 & 0.29 & 0.39 & -0.11 & 0.26 \\
\hline 5.06 & 153 & 0.98 & 0.50 & 0.35 & 0.79 & 0.02 & -0.02 & 26.4 & 145 & 0.88 & 0.80 & 0.19 & 0.40 & -0.01 & 0.19 \\
\hline 5.16 & 155 & 1.00 & 0.65 & 0.49 & 0.55 & 0.09 & -0.14 & 26.9 & 148 & 0.95 & 0.54 & 0.48 & 0.63 & -0.16 & 0.03 \\
\hline 5.26 & 158 & 0.98 & 0.34 & 0.55 & 0.65 & 0.36 & -0.10 & 27.4 & 150 & 0.94 & 0.33 & 0.34 & 0.79 & -0.27 & 0.14 \\
\hline 5.36 & 161 & 0.97 & 0.43 & 0.46 & 0.75 & 0.09 & 0.09 & 27.9 & 152 & 0.95 & 0.59 & 0.28 & 0.69 & -0.13 & -0.13 \\
\hline 5.46 & 165 & 0.97 & 0.66 & 0.33 & 0.60 & -0.26 & -0.01 & 28.4 & 154 & 0.97 & 0.61 & 0.19 & 0.74 & -0.10 & -0.07 \\
\hline 5.56 & 168 & 0.98 & 0.74 & 0.25 & 0.57 & -0.21 & -0.01 & 28.9 & 156 & 0.95 & 0.50 & 0.16 & 0.79 & -0.22 & -0.03 \\
\hline 5.66 & 171 & 0.98 & 0.73 & 0.22 & 0.59 & -0.19 & 0.06 & 29.4 & 158 & 0.97 & 0.49 & 0.24 & 0.76 & -0.31 & -0.03 \\
\hline 5.76 & 174 & 0.97 & 0.61 & 0.25 & 0.71 & -0.16 & 0.07 & 29.9 & 160 & 0.96 & 0.13 & 0.47 & 0.83 & 0.13 & -0.11 \\
\hline 5.86 & 178 & 0.96 & 0.72 & 0.51 & 0.40 & -0.12 & 0.01 & 30.4 & 162 & 0.97 & 0.70 & 0.40 & 0.52 & 0.17 & -0.15 \\
\hline 5.96 & 181 & 0.96 & 0.59 & 0.54 & 0.56 & -0.08 & -0.07 & 30.9 & 164 & 0.98 & 0.45 & 0.44 & 0.72 & 0.24 & -0.08 \\
\hline 6.06 & 184 & 0.97 & 0.65 & 0.35 & 0.60 & -0.23 & 0.06 & 31.4 & 166 & 0.91 & 0.38 & 0.53 & 0.66 & 0.07 & -0.21 \\
\hline 6.16 & 187 & 0.96 & 0.41 & 0.83 & 0.29 & -0.03 & 0.10 & 31.9 & 168 & 0.93 & 0.23 & 0.26 & 0.89 & 0.16 & 0.02 \\
\hline 6.26 & 191 & 0.98 & 0.46 & 0.74 & 0.42 & 0.22 & 0.08 & 32.4 & 170 & 0.96 & 0.62 & 0.57 & 0.40 & -0.28 & -0.12 \\
\hline 6.36 & 194 & 0.97 & 0.48 & 0.68 & 0.50 & 0.01 & 0.18 & 32.9 & 172 & 0.99 & 0.69 & 0.19 & 0.65 & -0.24 & 0.04 \\
\hline 6.46 & 205 & 0.95 & 0.68 & 0.58 & 0.39 & 0.11 & 0.02 & 33.5 & 175 & 0.97 & 0.66 & 0.20 & 0.71 & 0.02 & 0.07 \\
\hline 6.56 & 211 & 0.99 & 0.57 & 0.74 & 0.33 & -0.06 & -0.05 & 34 & 177 & 0.97 & 0.77 & 0.16 & 0.59 & -0.03 & 0.05 \\
\hline 6.66 & 216 & 0.98 & 0.61 & 0.64 & 0.43 & -0.06 & -0.04 & 34.5 & 179 & 0.99 & 0.70 & 0.17 & 0.67 & -0.09 & -0.04 \\
\hline 6.76 & 220 & 0.97 & 0.61 & 0.58 & 0.50 & -0.06 & -0.08 & 35 & 182 & 0.99 & 0.71 & 0.32 & 0.61 & -0.04 & 0.11 \\
\hline 6.86 & 224 & 0.95 & 0.49 & 0.46 & 0.70 & -0.01 & -0.02 & 35.5 & 185 & 0.99 & 0.90 & 0.29 & 0.31 & 0.05 & 0.06 \\
\hline 6.96 & 228 & 0.98 & 0.35 & 0.39 & 0.82 & -0.10 & 0.15 & 36 & 188 & 0.99 & 0.87 & 0.28 & 0.37 & 0.14 & 0.04 \\
\hline 7.06 & 231 & 0.98 & 0.52 & 0.54 & 0.57 & -0.29 & 0.01 & 36.5 & 192 & 1.00 & 0.96 & 0.18 & 0.21 & -0.04 & 0.06 \\
\hline 7.16 & 234 & 0.97 & 0.37 & 0.79 & 0.42 & 0.16 & -0.09 & 37 & 197 & 0.99 & 0.93 & 0.24 & 0.26 & 0.06 & 0.02 \\
\hline 7.26 & 237 & 0.98 & 0.40 & 0.84 & 0.35 & -0.06 & -0.01 & 37.5 & 201 & 0.99 & 0.88 & 0.31 & 0.32 & 0.13 & -0.02 \\
\hline 7.36 & 239 & 0.99 & 0.51 & 0.74 & 0.42 & -0.07 & 0.03 & 38 & 206 & 0.99 & 0.90 & 0.27 & 0.32 & -0.06 & -0.04 \\
\hline
\end{tabular}


D. M. ANDERSON, W. L. PRELL

Appendix B (continued).

\begin{tabular}{|c|c|c|c|c|c|c|c|c|c|c|c|c|c|c|c|}
\hline \multicolumn{3}{|c|}{ Core RC2761 } & \multirow[b]{2}{*}{ F1 } & \multirow[b]{2}{*}{ F2 } & \multirow[b]{2}{*}{ F3 } & \multirow[b]{2}{*}{ F4 } & \multirow[b]{2}{*}{ F5 } & \multicolumn{3}{|c|}{ Hole 723B } & \multirow[b]{2}{*}{ F1 } & \multirow[b]{2}{*}{ F2 } & \multirow[b]{2}{*}{ F3 } & \multirow[b]{2}{*}{ F4 } & \multirow[b]{2}{*}{ F5 } \\
\hline $\begin{array}{l}\text { Depth } \\
\text { (m) }\end{array}$ & $\begin{array}{l}\text { Age } \\
\text { (k.y.) }\end{array}$ & Communality & & & & & & $\begin{array}{l}\text { Depth } \\
\text { (mbsf) }\end{array}$ & $\begin{array}{c}\text { Age } \\
\text { (k.y.) }\end{array}$ & Communality & & & & & \\
\hline 7.46 & 242 & 0.94 & 0.47 & 0.64 & 0.56 & 0.02 & -0.01 & 38.5 & 210 & 0.99 & 0.84 & 0.30 & 0.42 & -0.10 & 0.01 \\
\hline 7.56 & 244 & 0.99 & 0.52 & 0.47 & 0.69 & -0.08 & 0.05 & 39 & 215 & 0.98 & 0.81 & 0.21 & 0.50 & -0.18 & 0.00 \\
\hline 7.66 & 247 & 0.99 & 0.43 & 0.59 & 0.66 & -0.17 & -0.00 & 39.5 & 218 & 0.97 & 0.83 & 0.21 & 0.48 & -0.04 & 0.02 \\
\hline 7.76 & 249 & 0.98 & 0.44 & 0.53 & 0.70 & -0.13 & -0.01 & 40 & 221 & 0.97 & 0.80 & 0.21 & 0.53 & -0.01 & -0.05 \\
\hline 7.86 & 251 & 0.99 & 0.70 & 0.38 & 0.59 & -0.02 & -0.10 & 40.5 & 224 & 0.97 & 0.82 & 0.19 & 0.50 & -0.11 & 0.04 \\
\hline 7.96 & 254 & 0.96 & 0.71 & 0.32 & 0.56 & -0.17 & -0.12 & 41 & 227 & 0.98 & 0.69 & 0.45 & 0.54 & 0.08 & -0.07 \\
\hline 8.06 & 256 & 0.98 & 0.80 & 0.20 & 0.53 & -0.13 & -0.03 & 41.5 & 230 & 0.99 & 0.81 & 0.32 & 0.46 & -0.01 & -0.09 \\
\hline 8.16 & 258 & 0.99 & 0.76 & 0.27 & 0.56 & -0.04 & -0.14 & 42 & 233 & 0.97 & 0.75 & 0.31 & 0.55 & -0.06 & -0.07 \\
\hline 8.26 & 261 & 0.99 & 0.80 & 0.30 & 0.51 & 0.00 & -0.03 & 42.5 & 236 & 0.99 & 0.80 & 0.33 & 0.47 & -0.10 & -0.08 \\
\hline 8.36 & 263 & 0.99 & 0.83 & 0.30 & 0.45 & -0.02 & -0.10 & 43 & 239 & 0.93 & 0.67 & 0.33 & 0.60 & -0.11 & -0.03 \\
\hline 8.46 & 266 & 0.98 & 0.30 & 0.45 & 0.82 & 0.01 & -0.04 & 43.1 & 239 & 0.94 & 0.50 & 0.34 & 0.66 & -0.34 & 0.11 \\
\hline 8.56 & 269 & 0.95 & 0.44 & 0.44 & 0.74 & 0.11 & -0.04 & 43.6 & 242 & 0.92 & 0.42 & 0.42 & 0.72 & 0.24 & -0.04 \\
\hline 8.66 & 272 & 0.96 & 0.31 & 0.39 & 0.84 & 0.10 & 0.08 & 44.1 & 245 & 0.98 & 0.73 & 0.40 & 0.53 & -0.02 & -0.01 \\
\hline 8.76 & 276 & 0.97 & 0.21 & 0.39 & 0.88 & -0.02 & 0.02 & 44.6 & 247 & 0.97 & 0.32 & 0.74 & 0.47 & -0.14 & -0.29 \\
\hline 8.86 & 279 & 0.99 & 0.26 & 0.51 & 0.79 & -0.19 & -0.00 & 45.1 & 250 & 0.99 & 0.85 & 0.15 & 0.46 & -0.19 & -0.03 \\
\hline 8.96 & 283 & 0.99 & 0.25 & 0.83 & 0.45 & -0.13 & 0.07 & 45.6 & 252 & 0.98 & 0.80 & 0.31 & 0.49 & -0.04 & -0.05 \\
\hline 9.06 & 287 & 0.99 & 0.47 & 0.79 & 0.36 & -0.17 & -0.00 & 46.1 & 255 & 0.99 & 0.84 & 0.27 & 0.46 & 0.06 & 0.00 \\
\hline 9.16 & 290 & 0.98 & 0.36 & 0.62 & 0.68 & 0.02 & 0.04 & 46.6 & 257 & 0.94 & 0.78 & 0.30 & 0.48 & -0.03 & -0.06 \\
\hline 9.26 & 293 & 0.98 & 0.34 & 0.57 & 0.73 & -0.08 & 0.04 & 47.1 & 259 & 0.99 & 0.85 & 0.30 & 0.39 & -0.07 & -0.08 \\
\hline 9.36 & 296 & 0.98 & 0.23 & 0.81 & 0.53 & 0.00 & -0.06 & 47.6 & 261 & 0.98 & 0.84 & 0.30 & 0.41 & 0.08 & -0.06 \\
\hline \multirow[t]{15}{*}{9.46} & 299 & 0.95 & 0.21 & 0.79 & 0.44 & 0.26 & -0.16 & 48.1 & 263 & 0.97 & 0.67 & 0.28 & 0.65 & 0.14 & 0.03 \\
\hline & & & & & & & & 48.6 & 266 & 0.97 & 0.64 & 0.27 & 0.69 & -0.06 & 0.05 \\
\hline & & & & & & & & 49.1 & 268 & 0.95 & 0.72 & 0.23 & 0.60 & -0.09 & 0.04 \\
\hline & & & & & & & & 49.6 & 270 & 0.88 & 0.63 & 0.25 & 0.64 & -0.01 & 0.09 \\
\hline & & & & & & & & 50.1 & 273 & 0.98 & 0.78 & 0.29 & 0.50 & -0.18 & 0.04 \\
\hline & & & & & & & & 50.6 & 275 & 0.98 & 0.83 & 0.27 & 0.46 & -0.10 & -0.07 \\
\hline & & & & & & & & 51.1 & 278 & 0.94 & 0.77 & 0.36 & 0.46 & 0.03 & 0.10 \\
\hline & & & & & & & & 51.6 & 280 & 0.91 & 0.49 & 0.32 & 0.71 & 0.25 & 0.04 \\
\hline & & & & & & & & 52.1 & 283 & 0.95 & 0.53 & 0.44 & 0.64 & 0.26 & 0.02 \\
\hline & & & & & & & & 52.6 & 286 & 0.98 & 0.60 & 0.38 & 0.67 & 0.01 & 0.13 \\
\hline & & & & & & & & 52.9 & 288 & 0.95 & 0.64 & 0.54 & 0.46 & 0.18 & 0.08 \\
\hline & & & & & & & & 53.4 & 292 & 0.96 & 0.63 & 0.49 & 0.50 & 0.25 & 0.13 \\
\hline & & & & & & & & 53.9 & 297 & 0.98 & 0.51 & 0.63 & 0.50 & 0.24 & 0.12 \\
\hline & & & & & & & & 54.4 & 302 & 0.98 & 0.63 & 0.64 & 0.39 & 0.02 & 0.18 \\
\hline & & & & & & & & 54.9 & 307 & 0.98 & 0.62 & 0.68 & 0.31 & -0.03 & 0.21 \\
\hline
\end{tabular}

